\title{
Dystocia due to Conjoined Twin Foetus in a Non-descriptive Ewe
}

\author{
N. Balamurugan ${ }^{1 *}$ and T. Mohanapriya ${ }^{2}$ \\ ${ }^{1}$ Veterinary Dispensary, Ayyanaroothu, Thoothukudi-628952, Tamil Nadu, India \\ ${ }^{2}$ Department of veterinary Pathology, Veterinary College and Research Institute (TANUVAS), \\ Tirunelveli - 627358, India \\ *Corresponding author
}

\section{A B S T R A C T}

\section{Keywords}

Non descriptive ewe, Dystocia, Shoulder Flexion, Monocephalic, Conjoined twin foetus

\section{Article Info}

Accepted:

15 December 2019

Available Online:

20 January 2020
The present case reports the successful management of dystocia in nondescript ewe due to conjoined twin monster foetus. A full term pregnant ewe in its second parity was brought to the veterinary dispensary Ayyanaroothu, Tutucorin with a history of abdominal straining and not able to deliver the young one. Per vaginal examination revealed presence of a foetus in anterior presentation with left shoulder flexion. Shoulder flexion was corrected and a dead monocephalic conjoined twin foetus was relieved by gentle traction. The ewe was treated with broad spectrum antibiotic, anti inflammatory and ecbolic drugs. The ewe recovered uneventfully.

\section{Introduction}

Generally dystocia may be of fetal or maternal origin (Noakes et al., 2009). The incidence of dystocia in small ruminants, is low compared to large ruminants $(<5 \%)$ (Bhattacharyya et al., 2015). Dystocia or difficult in birth can occur as a result of abnormal fetal presentation or position but normal births can occur despite such abnormalities. Fetal dystocia occurred mainly due to oversize, mal-disposition, and monsters (Noakes et al., 2009). Conjoined or fused twins arise from incomplete division of a single embryo during the primitive streak stage. The incidence of conjoined twins is reported from 1 in 50,000 to 1 in 100,000 births (Unver et al., 2007).

\section{History and clinical signs}

A full term pregnant non-descript sheep in its second parity weighing about $30 \mathrm{Kg}$ was presented to veterinary dispensary, Ayyanaroothu, Tuticorin. The owner reported that the ewe had constant abdominal straining 
from yesterday night and not able to deliver the foetus with ruptured water bag two hours before. The ewe was in standing posture with vaginal discharge when presented to the dispensary. Vital parameters were within the normal ranges. Vaginal examination revealed fully dilated cervix and the foetus was in anterior longitudinal presentation, dorsosacral position with left shoulder flexion with no fetal reflex.

\section{Treatment and Discussion}

Caudal epidural anesthesia was administered between the first and second inter-coccygeal vertebrae using $2 \mathrm{~mL}$ of $2 \%$ Lignocaine hydrochloride to control straining. After proper lubrication the foetus was repelled, the left shoulder flexion was corrected and a dead monster foetus was relieved by gentle traction. Fetal examination revealed conjoined twin with one head (Monocephalus), eight limbs and abdomen of one foetus fused with other (Figure). Based on the morphology, the dead monstrous condition was diagnosed as monocephalus with posterior twining. This abnormality of the foetus caused dystocia in the present case.

After successful relieving of dead monster the dam was administered with antibiotic injection Enrofloxacin@5 mg / Kg Bwt, analgesic @ $0.5 \mathrm{mg} / \mathrm{Kg} \mathrm{Bwt}$, for three days and uterotone ecbolic was administered 10 $\mathrm{mL}$ orally for 5 days to the hasten the involution of uterus. After 14 days the ewe had good feeding habit with uneventful recovery. Incidence of monstrosities in livestock is of great importance because of genetic transmission of such malformation (Balamurugan et al., 2018). Foetal monstrosities represent less than $1 \%$ of all observed congenital malformation in bovine and caprine species (Roberts, 1971). Etiology of such monsters is usually unknown but considered to be due to chromosomal defects (Morrow, 1986). The affected monster foetus will be carried to term and such fully developed monster usually resulted in dystocia which required considerable skill to ensure a safe delivery without damage to the dam (Sharma et al., 2001).

Figure.1 Monster - Monocephalus, eight limbs and abdomen of one foetus fused with other

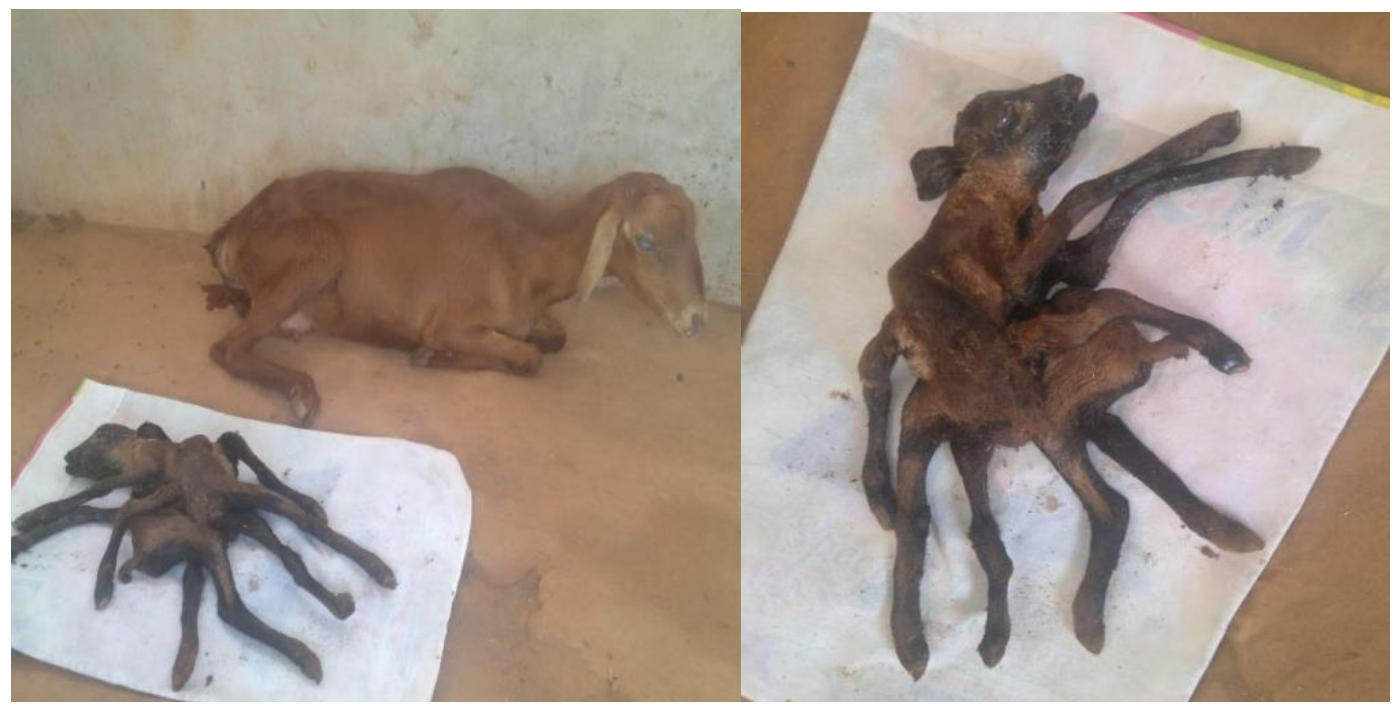


It is concluded that dystocia in goats can be successfully managed per-vaginum in fetal malposition and monster foetus cases with normal fetal size. The loss of dam can be prevented by reducing the undue delay in the presentation of the case.

\section{Acknowledgements}

The authors are thankful to the Department of Animal Husbandry, Tamilnadu for providing the facilities.

\section{References}

Balamurugan B, Deepesh Gautam, Sasikala R, Ramamoorthy $\mathrm{M}$ and Sowbhranya $\mathrm{C}$, 2018. Dystocia due to perosomus horridus monster in a nondescript doe- a rare case report. Int. J. Environ. Sci.
Technol., 7(1): 96 - 99

Bhattacharyya, Mujeeb -u- R. Fazili, Fayaz A. Bhat, Bashir A. Buchoo. 2015. Prevalence of Dystocia in Sheep and Goats: A Study of 70 Cases (20042011), J. Avd Vet Res. Vol. 5, 14-20.

Morrow, D.A. (1986) Current Therapy in Theriogenology. W.B. Saunders Co., Philadelphia, USA. pp 486.

Noakes D.E (2009). Arthur's veterinary reproduction and obstetrics. Saunders $\mathrm{WB}, 8^{\text {th }}$ edition

Sharma A., Bishat V.B., Negi A.S and Negi B.S. 2001. Dystocia due to perosomus horridusin in ewe: A case report. Ind. Vet. J. 78: 1141

Unver Kilinc M, Ozyurtlu N. 2007. Cranial Duplication (Dicephalus) in a Lamb. Turk. J Vet Anim Sci. 31(6):415-417

\section{How to cite this article:}

Balamurugan, N. and Mohanapriya, T. 2020. Dystocia due to Conjoined Twin Foetus in a Nondescriptive Ewe. Int.J.Curr.Microbiol.App.Sci. 9(01): 938-940.

doi: https://doi.org/10.20546/ijcmas.2020.901.105 